\title{
Release of phosphorus, aluminium and iron in fractionation of inorganic soil phosphorus
}

\author{
RAINA NISKANEN \\ University of Helsinki, Department of Agricultural Chemistry, \\ SF-00710 HELSINKI, Finland
}

\begin{abstract}
Release of phosphorus, aluminium and iron by a modified CHANG and JACKSON procedure was studied in five mineral soils. Quantities of aluminium and iron released during the procedure and extracted by acid ammonium oxalate were compared. The extractability of $\mathrm{P}, \mathrm{Al}$ and $\mathrm{Fe}$ by $1 \mathrm{M} \mathrm{NH}_{4} \mathrm{Cl}$ and that of $\mathrm{Al}$ and $\mathrm{Fe}$ by alkaline $0.5 \mathrm{M} \mathrm{NH}_{4} \mathrm{~F}$ was poor. Proportions of $\mathrm{P}$ extracted by $0.5 \mathrm{M} \mathrm{NH}_{4} \mathrm{~F}(0.2-10.4 \mathrm{mmol} / \mathrm{kg}$ soil $)$ and $0.1 \mathrm{M} \mathrm{NaOH}(0.1-$ $9.8 \mathrm{mmol} / \mathrm{kg}$ soil) were related to the molar ratio of oxalate-extractable iron and aluminium. P extracted by $0.25 \mathrm{M} \mathrm{H}_{2} \mathrm{SO}_{4}$ amounted to $2.1-12.2 \mathrm{mmol} / \mathrm{kg}$ soil. Al extracted by $0.1 \mathrm{M}$ $\mathrm{NaOH}\left(7-174 \mathrm{mmol} / \mathrm{kg}\right.$ soil) and $0.25 \mathrm{M} \mathrm{H}_{2} \mathrm{SO}_{4}(17-112 \mathrm{mmol} / \mathrm{kg}$ soil) amounted to $55-94 \%$ and $16-245 \%$ of oxalate-extractable $\mathrm{Al}$, respectively. Fe released by $0.1 \mathrm{M} \mathrm{NaOH}$ $\left(1-10 \mathrm{mmol} / \mathrm{kg}\right.$ soil) and $0.25 \mathrm{M} \mathrm{H}_{2} \mathrm{SO}_{4}(30-196 \mathrm{mmol} / \mathrm{kg}$ soil $)$ amounted to $1-13 \%$ and $62-272 \%$ of oxalate-extractable Fe, respectively. In total, $91-309 \%$ of oxalate-extractable $\mathrm{Al}$ and $70-285 \%$ of oxalate-extractable Fe were released by $\mathrm{NaOH}$ and $\mathrm{H}_{2} \mathrm{SO}_{4}$.
\end{abstract}

Index words: phosphorus fractions, extractable aluminium and iron

\section{Introduction}

The fractionation procedure developed by ChANG and Jackson (1957) is frequently used in estimation of inorganic soil phosphorus (e.g. Kaila 1964, Hartikainen 1979). Phosphorus fractions bound by aluminium and iron oxides and phosphorus of calcium phosphates such as apatite are considered to be extracted successively in the procedure. The reagents used are known partly to extract soil aluminium and iron, but the amounts released besides phosphorus are infrequently determined. The aim of this study was to examine the simultaneous release of phosphorus, aluminium and iron in fractionation and to compare the extractability of aluminium and iron with their extractability by acid ammonium oxalate.

\section{Material and methods}

The material consisted of five mineral soil samples from the Viikki Experimental Farm, 


\begin{tabular}{|c|c|c|c|c|c|}
\hline & \multicolumn{5}{|c|}{ Soil sample } \\
\hline & 1 & 2 & 3 & 4 & 5 \\
\hline Sampling depth, cm & $0-20$ & $20-40$ & $20-40$ & $0-20$ & $20-40$ \\
\hline $\mathrm{pH}\left(\mathrm{CaCl}_{2}\right)$ & 5.1 & 4.6 & 4.8 & 5.3 & 5.0 \\
\hline Org. C, \% & 3.6 & 0.8 & 2.6 & 4.4 & 1.0 \\
\hline \multicolumn{6}{|l|}{ Particle-size distribution, $\%$} \\
\hline$<0.002 \mathrm{~mm}$ & 13 & 2 & 47 & 10 & 26 \\
\hline $0.002-0.02 \mathrm{~mm}$ & 20 & 1 & 30 & 7 & 2 \\
\hline $0.02-0.06 \mathrm{~mm}$ & 27 & 7 & 18 & 15 & 23 \\
\hline $0.06-0.20 \mathrm{~mm}$ & 31 & 35 & 5 & 61 & 42 \\
\hline $0.20-2.00 \mathrm{~mm}$ & 9 & 56 & 0 & 7 & 6 \\
\hline Oxalate-soluble $\mathrm{Al} \mathrm{mmol} / \mathrm{kg}$ & 186 & 104 & 76 & 23 & 11 \\
\hline Oxalate-soluble $\mathrm{Fe} \mathrm{mmol} / \mathrm{kg}$ & 53 & 32 & 224 & 140 & 11 \\
\hline Oxalate-soluble $\mathrm{Fe} / \mathrm{Al}$ & 0.3 & 0.3 & 2.9 & 6.1 & 1.0 \\
\hline
\end{tabular}

University of Helsinki, (Nos. 2-4) and South Karelia (Imatra) (No. 1): Nos. 1 and 4 from plough layer $(0-20 \mathrm{~cm})$ and Nos. 3 and 5 from deeper layer $(20-40 \mathrm{~cm})$ of cultivated soils, No. 2 from deeper layer of virgin soil (Table 1). The samples were air-dried and ground to pass a $2-\mathrm{mm}$ sieve. Soil $\mathrm{pH}$ was measured in soil- $0.01 \mathrm{M} \mathrm{CaCl}_{2}$ suspension $(1: 2.5 \mathrm{v} / \mathrm{v})$ (RYTI 1965). The organic carbon content was determined by a modified (GRAham 1948) Alten wet combustion method. The particle-size distribution of the inorganic matter of soil was determined by the pipette method (ELONEN 1971). The amorphous aluminium and iron were extracted by acid ammonium oxalate $(0.18 \mathrm{M}$ ammonium oxalate, $0.10 \mathrm{M}$ oxalic acid, pH 3.3, 1:20 w/v) (TАMм 1922) and determined by atomic absorption spectrophotometry.

The soils were extracted by a modified CHANG and JACKSON (1957) fractionation procedure using a slightly alkaline $\mathrm{NH}_{4} \mathrm{~F}(\mathrm{pH}$ $8.5)$ as recommended by FIFE (1959). The extracts were analysed for phosphorus by a molybdenum blue method modified by KAILA (1955) and for aluminium and iron by atomic absorption spectrophotometry. Fractionation was carried out in triplicate.

\section{Results and discussion}

In the fractionation procedure, the extractability of phosphorus, aluminium and iron by $1 \mathrm{M} \mathrm{NH}_{4} \mathrm{Cl}$ was poor (Table 2). According to Kaila $(1964,1965)$ and Hartikainen (1979), the extractability of phosphorus by 1 $\mathrm{M} \mathrm{NH} \mathrm{H}_{4} \mathrm{Cl}$ is generally low in Finnish mineral soils. As an anion of a strong acid, $\mathrm{Cl}^{-}$cannot participate in ligand exchange reactions with phosphate complexed by aluminium and iron oxides. The content of phosphate extractable by $\mathrm{NH}_{4} \mathrm{Cl}$ is worth mentioning only when the sorption capacity of soil is covered with phosphate. In the experimental soils, however, the ratio of fractionated phosphorus to oxalate-soluble aluminium and iron was low.

According to Kalla (1964), the occurrence of phosphorus in the forms soluble in $\mathrm{NH}_{4} \mathrm{~F}$ and $\mathrm{NaOH}$ is to some extent regulated by the molar ratio of active aluminium and iron contents in Finnish soils. More phosphorus was extracted by $0.1 \mathrm{M} \mathrm{NaOH}$ than by $0.5 \mathrm{M}$ $\mathrm{NH}_{4} \mathrm{~F}$ from soils No. 3 and 4 which contained more oxalate-extractable iron (mmol/ $\mathrm{kg}$ soil) than aluminium (Table 2 ). In the other soils, the $\mathrm{NH}_{4} \mathrm{~F}$-soluble fraction was greater than the $\mathrm{NaOH}$-soluble one.

No aluminium was found in $\mathrm{NH}_{4} \mathrm{~F}$ extracts and iron was poorly soluble (Table 2 ). The fluoride-soluble iron in soils No. 1 and 2 amounted to $6-7 \%$, in the other soils to less than $2 \%$ of the oxalate-soluble iron. Fluoride does not measurably complex ferric iron at a pH above 8.0 (FIFE 1959). 
Table 2. Soil $\mathrm{P}, \mathrm{Al}$ and $\mathrm{Fe}$ ( $\mathrm{mmol} / \mathrm{kg}$ soil) extracted successively by the CHANG and JAcKson procedure.

\begin{tabular}{|c|c|c|c|c|c|}
\hline & \multicolumn{5}{|c|}{ Soil sample } \\
\hline & 1 & 2 & 3 & 4 & 5 \\
\hline $\mathrm{P}$ extracted by $1 \mathrm{M} \mathrm{NH}{ }_{4} \mathrm{Cl}$ & 0.0 & 0.0 & 0.0 & 0.0 & 0.0 \\
\hline P extracted by $0.5 \mathrm{M} \mathrm{NH}_{4} \mathrm{~F}$ & 10.4 & 2.3 & 0.8 & 0.7 & 0.2 \\
\hline P extracted by $0.1 \mathrm{M} \mathrm{NaOH}$ & 3.9 & 0.9 & 9.8 & 6.0 & 0.1 \\
\hline P extracted by $0.25 \mathrm{M} \mathrm{H}_{2} \mathrm{SO}_{4}$ & 2.1 & 4.8 & 5.1 & 6.6 & 12.2 \\
\hline $\mathrm{NaOH}-\mathrm{P} / \mathrm{NH}_{4} \mathrm{~F}-\mathrm{P}$ & 0.4 & 0.4 & 12.3 & 8.6 & 0.5 \\
\hline Al extracted by $1 \mathrm{M} \mathrm{NH}_{4} \mathrm{Cl}$ & 0 & 0 & 0 & 0 & 0 \\
\hline $\mathrm{Al}$ extracted by $0.5 \mathrm{M} \mathrm{NH}_{4} \mathrm{~F}$ & 0 & 0 & 0 & 0 & 0 \\
\hline Al extracted by $0.1 \mathrm{M} \mathrm{NaOH}$ & 174 & 78 & 42 & 21 & 7 \\
\hline Al extracted by $0.25 \mathrm{M} \mathrm{H}_{2} \mathrm{SO}_{4}$ & 85 & 17 & 112 & 22 & 27 \\
\hline Fe extracted by $1 \mathrm{M} \mathrm{NH}_{4} \mathrm{Cl}$ & 0 & 0 & 0 & 0 & 2 \\
\hline Fe extracted by $0.5 \mathrm{M} \mathrm{NH}_{4} \mathrm{~F}$ & 3 & 2 & 0 & 3 & 0 \\
\hline Fe extracted by $0.1 \mathrm{M} \mathrm{NaOH}$ & 2 & 2 & 3 & 10 & 1 \\
\hline Fe extracted by $0.25 \mathrm{M} \mathrm{H}_{2} \mathrm{SO}_{4}$ & 69 & 31 & 196 & 87 & 30 \\
\hline
\end{tabular}

$\mathrm{NaOH}$ is frequently used in extraction of humic matter and oxides of aluminium and silica (JACKSON 1965). In the experimental soils, $0.1 \mathrm{M} \mathrm{NaOH}$-soluble aluminium amounted to over $50 \%(55-94 \%)$ of oxalate-extractable aluminium, $\mathrm{NaOH}$-extractable iron only to $1-13 \%$ of oxalate-extractable iron. According to Aleksandrova (1960), the solubility of iron in $0.1 \mathrm{M} \mathrm{NaOH}$ is low. Because humic matter is extracted by $\mathrm{NaOH}$ and alkaline $\mathrm{NH}_{4} \mathrm{~F}$, it is possible that the iron released by these reagents is derived from humic complexes.

The proportion of $\mathrm{H}_{2} \mathrm{SO}_{4}$-soluble phosphorus was high in soils No. 2, 4 and 5 which were predominantly coarse (Table 2 ). About half of the fractionated phosphorus in soils No. 2 and 4 was extracted by $\mathrm{H}_{2} \mathrm{SO}_{4}$. In soil No. 5 of low oxalate-soluble aluminium and iron content, phosphorus was mainly $\mathrm{H}_{2} \mathrm{SO}_{4}$ soluble. In soils No. 1 and 3 of high aluminium and iron content, $\mathrm{H}_{2} \mathrm{SO}_{4}$ extracted 13 and $33 \%$ of the fractionated phosphorus, respectively.

Amply of aluminium and iron was extracted by $0.25 \mathrm{M} \mathrm{H}_{2} \mathrm{SO}_{4}$ (Table 2) which is an effective extractant of iron oxides (Hsu 1964). $\mathrm{H}_{2} \mathrm{SO}_{4}$-soluble aluminium in soils No. 1 and 2 amounted to 46 and $16 \%$, respectively, and in soils No. $3-5$ to $96-245 \%$ of oxalateextractable aluminium. In the fractionation procedure, iron was mainly released by $\mathrm{H}_{2} \mathrm{SO}_{4}, 62 \%$ in soil No. 4 and $97-272 \%$ of oxalate-extractable iron in the other soils.

In the course of the fractionation procedure, large amounts of aluminium and iron were released besides phosphorus by $0.1 \mathrm{M}$ $\mathrm{NaOH}$ and $0.25 \mathrm{M} \mathrm{H}_{2} \mathrm{SO}_{4}$, release of the latter being particularly drastic. In total, these two reagents extracted aluminium and iron in amounts corresponding to $91-309 \%$ and $70-285 \%$ of oxalate-extractable aluminium and iron, respectively.

ChAng and Jackson (1957) developed their procedure for fractionation of soil phosphorus into discrete chemical forms using aluminium, iron and calcium phosphate minerals variscite, strengite and apatite as controls. However, variscite and strengite are not likely to occur in normal agricultural soil. The solubility product of variscite controls the phosphorus concentration in solution only when the $\mathrm{pH}$ of the equilibrium solution is below 3.1 (BACHE 1963). At higher $\mathrm{pH}$ values, variscite dissolves incongruently, whereby a more basic solid phase of aluminium hydroxyphosphate is formed (TAYLOR and GURNEY 1962 a, b, 1964). Strengite is never likely to be in equilibrium with any soil solution (BACHE 1963).

According to the modern concept, adsorbed phosphate is more important in soil than dis- 
crete phosphate compounds. In acid soil, phosphate is largely adsorbed through ligand exchange onto surfaces of aluminium and iron oxides. From this viewpoint, the soil phosphorus available is best extracted by solutions which release phosphate through ligand exchange without dissolution of aluminium or iron from the oxide surface. In the fractionation procedure the alkaline ammonium fluoride was the extractant best fulfilling these presumptions. The oxides of aluminium were largely dissolved by $\mathrm{NaOH}$ and $\mathrm{H}_{2} \mathrm{SO}_{4}$, the latter dissolving effectively also iron oxides. According to KhanNa and Ulrich (1967), in

\section{References}

Aleksandrova, L. N. 1960. The use of sodium pyrophosphate for isolating free humic substances and their organic-mineral compounds from the soil. Soviet Soil Sci. 2: 190-197.

BACHE, B. W. 1963. Aluminium and iron phosphate studies relating to soils. I. Solution and hydrolysis of variscite and strengite. J. Soil Sci. 14: 113-123.

Bromfieid, S. M. 1967 a. Phosphate sorbing sites in acid soils. An examination of ammonium fluoride as a selective extractant for aluminum-bound phosphate in phosphated soils. Aust. J. Soil Res. 5: 93-102.

$-1967 \mathrm{~b}$. An examination of the use of ammonium fluoride as a selective extractant for aluminum-bound phosphate in partially phosphated systems. Aust. J. Soil Res. 5: 225-234.

-1970 . The inadequacy of corrections for resorption of phosphate during the extraction of aluminum-bound soil phosphate. Soil Sci. 109: 388-390.

Chang, S. C. \& Jackson, M. L. 1957. Fractionation of soil phosphorus. Soil Sci. 84: 133-144.

Elonen, P. 1971. Particle-size analysis of soil. Acta Agr. Fenn. 122: 1-122.

FifE, C. V. 1959. An evaluation of ammonium fluoride as a selective extractant for aluminium-bound soil phosphate: II Preliminary studies on soils. Soil Sci. 87: 83-88.

Graham, E. R. 1948. Determination of soil organic matter by means of a photoelectric colorimeter. Soil Sci. 65: $181-183$.

Hartikainen, H. 1979. Phosphorus and its reactions in terrestrial soils and lake sediments. J. Scient. Agric. Soc. Finl. 51: 537-624.

Hsu, P. H. 1964. Adsorption of phosphate by aluminum and iron in soils. Soil Sci. Soc. Am. Proc. 28: 474-478.

JACKSON, M. L. 1965. Free oxides, hydroxides, and amorphous alumino-silicates. Methods of soil analy- acid soils, the $\mathrm{H}_{2} \mathrm{SO}_{4}$-soluble phosphates cannot be designated solely as calcium phosphates. They may also include acid-soluble portions of occluded phosphates.

Although the selectivity of the extractants for different forms of phosphate is limited (BROMFIELd $1967 \mathrm{a}, \mathrm{b}$, VAhtras and WiKLAN. DER 1970) and it varies in the original phosphate fraction during extraction (BROMFIELD 1970, Rajendran and Sutton 1970), the fractionation scheme of CHANG and JACKSON does, however, provide information on the general trends of phosphate transformation reactions. sis. Part I. Agronomy 9: 578-603.

KAILA, A. 1955. Studies on the colorimetric determination of phosphorus in soil extracts. Acta Agr. Fenn. 83: $25-47$.

- 1964. Fractions of inorganic phosphorus in Finnish mineral soils. J. Scient. Agric. Soc. Finl. 36: 1-13.

-1965 . Some phosphorus test values and fractions of inorganic phosphorus in soils. J. Scient. Agric. Soc. Finl. 37: 175-185.

Khanna, P. K. \& Ul.rich, B. 1967. Phosphatfraktionierung im Boden und isotopisch austauschbares Phosphat verschiedener Phosphatfraktionen. Z. Pflanzenernăhr., Düng., Bodenk. 117: 53-65.

Rajendran, N. \& Sutton, C. D. 1970. Re-sorption of soil phosphate during fractionation. J. Soil Sci. 21: 199-202.

Rvт, R. 1965. On the determination of soil pH. J. Scient. Agric. Soc. Finl. 37: 51-60.

TAMN, O. 1922. Eine Methode zur Bestimmung der anorganischen Komponente des Gelkomplexes im Boden. Statens Skogsförsöksanstalt. Medd. 19: 387-404. Stockholm.

TAYIor, A. W. \& GurneY, E. L. 1962 a. Solubility of amorphous aluminum phosphate. Soil Sci. 93: $241-245$.

- \& Gurney, E. L. 1962 b. Phosphate equilibria in acid soil. J. Soil Sci. 13: 187-197.

— \& Gurney, E. L. 1964. Solubility of variscite. Soil Sci. 98: 9-13.

VAhtras, K. \& WiKLAnder, L. 1970. Phosphate studies in soils: With special reference to Chang and Jackson's fractionation procedure. Lantbrukshögsk. Ann. 36: 115-134.

Ms received March 2, 1987 


\section{SELOSTUS}

\section{Fosforin, aluminiumin ja raudan uuttuminen fraktioitaessa maan epäorgaanista fosforia}

\section{Raina Niskanen \\ Helsingin yliopisto, Maanviljelyskemian laitos, $00710 \mathrm{Helsinki}$}

Fosforin, aluminiumin ja raudan uuttumista mukaillussa Changin ja Jacksonin fraktioinnissa tutkittiin viidellä kivennäismaalla. Fraktioinnissa uuttuneiden aluminiumin ja raudan pitoisuuksia verrattiin happamalla ammoniumoksalaatilla uuttuvan aluminiumin ja raudan pitoisuuksiin. Fosforin, aluminiumin ja raudan uuttuminen $1 \mathrm{M} \mathrm{NH}_{4} \mathrm{Cl}$ :lla sekä aluminiumin ja raudan uuttuminen emäksisellä $0.5 \mathrm{M} \mathrm{NH}_{4} \mathrm{~F}$ :lla oli văhäistă. Fluoridiuuttoisen fosforin $(0.2-10.4 \mathrm{mmol} / \mathrm{kg}$ maata) ja 0.1 $\mathrm{M} \mathrm{NaOH}$ :lla uuttuvan fosforin $(0.1-9.8 \mathrm{mmol} / \mathrm{kg}$ maata) osuudet fraktioinnissa uuttuvasta fosforista riippuivat oksalaattiuuttoisen raudan ja aluminiumin moolisuhteesta. $\mathrm{H}_{2} \mathrm{SO}_{4}$ :lla uuttui fosforia $2.1-12.2 \mathrm{mmol} / \mathrm{kg}$ maata. Aluminiumin uuttuminen $0.1 \mathrm{M} \mathrm{NaOH}$ :lla $(7-174$ $\mathrm{mmol} / \mathrm{kg}$ maata) ja $0.25 \mathrm{M} \mathrm{H}_{2} \mathrm{SO}_{4}: 1 \mathrm{la}(17-112 \mathrm{mmol} /$ kg maata) vastasi $55-94 \%$ ja $16-245 \%$ oksalaattiuuttoisesta aluminiumista. $\mathrm{NaOH}$-uuttoinen rauta $(1-10$ $\mathrm{mmol} / \mathrm{kg}$ maata) ja $\mathrm{H}_{2} \mathrm{SO}_{4}$-uuttoinen rauta $(30-196$ $\mathrm{mmol} / \mathrm{kg}$ maata) vastasivat $1-13 \%$ ja $62-272 \%$ oksalaattiuuttoisesta raudasta. $\mathrm{NaOH}$ :lla ja $\mathrm{H}_{2} \mathrm{SO}_{4}$ :lla uuttui yhteensä 91-309\% oksalaattiuuttoisesta aluminiumista ja $70-285 \%$ oksalaattiuuttoisesta raudasta. 